\title{
Serum-free microcarrier based production of replication deficient Influenza vaccine candidate virus lacking NS1 using Vero cells
}

\author{
Allen Chen ${ }^{1 \dagger}$, Swan Li Poh ${ }^{1 \dagger}$, Christian Dietzsch², Elisabeth Roethl², Mylene L Yan ${ }^{1}$ and Say Kong Ng ${ }^{1 *}$
}

\begin{abstract}
Background: Influenza virus is a major health concern that has huge impacts on the human society, and vaccination remains as one of the most effective ways to mitigate this disease. Comparing the two types of commercially available Influenza vaccine, the live attenuated virus vaccine is more cross-reactive and easier to administer than the traditional inactivated vaccines. One promising live attenuated Influenza vaccine that has completed Phase I clinical trial is deltaFLU, a deletion mutant lacking the viral Nonstructural Protein 1 (NS1) gene. As a consequence of this gene deletion, this mutant virus can only propagate effectively in cells with a deficient interferon-mediated antiviral response. To demonstrate the manufacturability of this vaccine candidate, a batch bioreactor production process using adherent Vero cells on microcarriers in commercially available animalcomponent free, serum-free media is described.

Results: Five commercially available animal-component free, serum-free media (SFM) were evaluated for growth of Vero cells in agitated Cytodex 1 spinner flask microcarrier cultures. EX-CELL Vero SFM achieved the highest cell concentration of $2.6 \times 10^{\wedge} \sigma \mathrm{cell} / \mathrm{s} / \mathrm{ml}$, whereas other SFM achieved about $1.2 \times 10^{\wedge} 6 \mathrm{cell} / \mathrm{s} / \mathrm{ml}$. Time points for infection between the late exponential and stationary phases of cell growth had no significant effect in the final virus titres. A virus yield of $7.6 \log _{10} \mathrm{TCID}_{50} / \mathrm{ml}$ was achieved using trypsin concentration of $10 \mu \mathrm{g} / \mathrm{ml}$ and $\mathrm{MOl}$ of 0.001 . The Influenza vaccine production process was scaled up to a 3 liter controlled stirred tank bioreactor to achieve a cell density of $2.7 \times 10^{\wedge} 6$ cells $/ \mathrm{ml}$ and virus titre of $8.3 \log _{10} \mathrm{TCID}_{50} / \mathrm{ml}$. Finally, the bioreactor system was tested for the production of the corresponding wild type H1N1 Influenza virus, which is conventionally used in the production of inactivated vaccine. High virus titres of up to $10 \log _{10} T C I D_{50} / \mathrm{ml}$ were achieved.

Conclusions: We describe for the first time the production of Influenza viruses using Vero cells in commercially available animal-component free, serum-free medium. This work can be used as a basis for efficient production of attenuated as well as wild type Influenza virus for research and vaccine production.
\end{abstract}

Keywords: Influenza, Vero, Microcarrier, NS1, Bioreactor

\section{Background}

Influenza virus is a major health concern that has huge impacts on the human society. Historically responsible for millions of deaths in pandemics, the virus also causes seasonal outbreaks during colder months in temperate regions which annually result in up to 500,000

\footnotetext{
* Correspondence: ng_say_kong@bti.a-star.edu.sg

+ Contributed equally

${ }^{1}$ Bioprocessing Technology Institute, Agency for Science, Technology and Research (A*STAR), 20 Biopolis Way, \#06-01, Centros, Singapore 138668,

Singapore

Full list of author information is available at the end of the article
}

deaths worldwide [1]. Although antiviral drugs for acute treatment are available in some countries, vaccination remains as one of the most effective ways to mitigate this disease.

Both inactivated vaccine and the live attenuated Influenza vaccines are commercially available. Although the live attenuated virus vaccine has been used in Russia since the 1960s [2], concerns regarding safety and possible virus shedding have precluded it from use in the rest of the world until recently: In 2003, a cold adapted, egg grown, live attenuated influenza virus vaccine by
C Biomed Central

() 2011 Chen et al; licensee BioMed Central Ltd. This is an Open Access article distributed under the terms of the Creative Commons Attribution License (http://creativecommons.org/licenses/by/2.0), which permits unrestricted use, distribution, and reproduction in any medium, provided the original work is properly cited. 
MedImmune was licensed for use in the US [3,4]. Live attenuated virus vaccines have the added advantage of being more cross-reactive than traditional inactivated vaccines [5-7]. This type of vaccine is also easier to administer, since it is delivered in the form of nasal sprays, compared to injections for the traditional inactivated influenza vaccines.

One promising live attenuated Influenza that has completed Phase I clinical trial is deltaFLU, a deletion mutant lacking the viral Nonstructural Protein 1 (NS1) gene developed by Avir Green Hills Biotechnology [8-12]. As NS1 is an interferon antagonist [13], the NS1 deletion virus is replication defective in interferon competent host systems, enabling its use as a live attenuated vaccine [9-11]. Another consequence of this gene deletion is that this virus vaccine can only propagate effectively in cells with a deficiency in the interferonmediated antiviral response [8]. Vero (African Green Monkey kidney) is one such cell line as the gene locus encoding the main Type I interferons, Interferon $\alpha$ and $\beta$, are missing from its genomic DNA $[14,15]$. Consequently, it has been previously demonstrated that the NS1 deletion Influenza virus grows efficiently in Vero cells, but not in MDCK or mice $[8,16,17]$. This NS1 deletion virus is also interesting because it may find applications in cancer therapy $[18,19]$ and other prophylactics [20].

Regardless of vaccine type (inactivated or live attenuated), virus vaccine production requires the initial step of propagating the Influenza viruses carrying the haemaglutinin and neuraminidase antigens of the strains that the vaccine is providing prophylaxis for. These viruses are traditionally propagated in embryonated hen eggs. Two important limitations of this process are the inflexible supply of high quality specific pathogen free (SPF) eggs and possible low titres of emerging viruses, such as the highly pathogenic Influenza A (H5N1) strain. To provide an alternative to egg-based vaccine production, mammalian cell culture based production has been developed in recent years [21]. This provides a flexible and scalable platform that can make use of existing biopharmaceutical infrastructure for Influenza vaccine production.

Three cell lines commonly used for Influenza virus production are the PER.C6 cells, MDCK (Madin-Darby Canine Kidney) and Vero (African Green Monkey Kidney). All three cell lines can be grown in serum-free media. While PER.C6 and MDCK can be cultured in suspension [22,23], microcarriers are commonly used for culturing MDCK [22,24-30] and Vero cells [31-34] because these cell lines are typically anchorage dependent. The seasonal and pandemic Influenza vaccine produced in MDCK cells by Novartis has gained various regulatory approvals in 2007 and 2009 respectively, while those produced in Vero cells by Baxter has also gained approvals in 2010 and 2009 respectively.

Although bioreactor production of Influenza virus has been developed, serum-free production processes described in literature commonly use proprietary inhouse cell culture media [24,25,29,30,32]. To our knowledge, there are a few reports describing Influenza virus production using MDCK cells in commercially available serum-free medium [21,26-28], while that using Vero cells is described in only one recent report [35] although the medium used contains animal components. Related literature described serum-free media for Vero cells $[36,37]$ and microcarrier bioreactor processes for the production of other viruses using Vero cells [37-46]. It is important to bridge this gap to provide a scalable animal-component free, serum-free platform for researchers and academics to produce different Influenza viruses using Vero cells.

In this report, we describe for the first time, a scalable bioreactor process for the production of Influenza A virus lacking NS1 in Vero cells using commercially available animal-component free, serum-free media. We chose to use Cytodex 1 microcarriers for our bioreactor cell culture, since this microcarrier has been previously reported for Vero cells [31,33,34,39-43,45,46]. We evaluated five commercially available animal-component free, serum-free media for Vero cells by comparing the cell yield in these media. The medium giving the highest cell densities was then used to develop the bioreactor process for Influenza virus production. This involved studies of parameters that will affect the virus production process, namely trypsin concentration, time-point of infection (TOI), and multiplicity of infection (MOI). These parameters were validated in classical stirred tank bioreactor processes. Finally, we also compared the production of the NS1 truncated Influenza A virus with that of the corresponding wild type Influenza A virus.

\section{Results and Discussion}

\section{Growth kinetics of Vero cell microcarrier culture in different SFMs}

The growth kinetics of Vero cells in the 5 commercially available animal-component free, serum-free media (SFM) were evaluated in $250 \mathrm{ml}$ spinner flasks. The media evaluated were OptiPro SFM (Invitrogen), VPSFM (Invitrogen), EX-CELL Vero SFM (SAFC Bioscience), Provero-1 (Lonza) and HyQ SFM4MegaVir (HyClone). The results are presented in Figure 1A. Poor attachment of cells to microcarriers and poor cell growth was observed in HyQ SFM4MegaVir, which consequentially yielded a low cell concentration of $4.5 \times 10^{5}$ cells/ml. OptiPro SFM, VP-SFM and Provero-1 SFM displayed similar cell growth profiles, yielding cell concentrations of $1.2 \times 10^{6}$ cells $/ \mathrm{ml}$ with viability above 


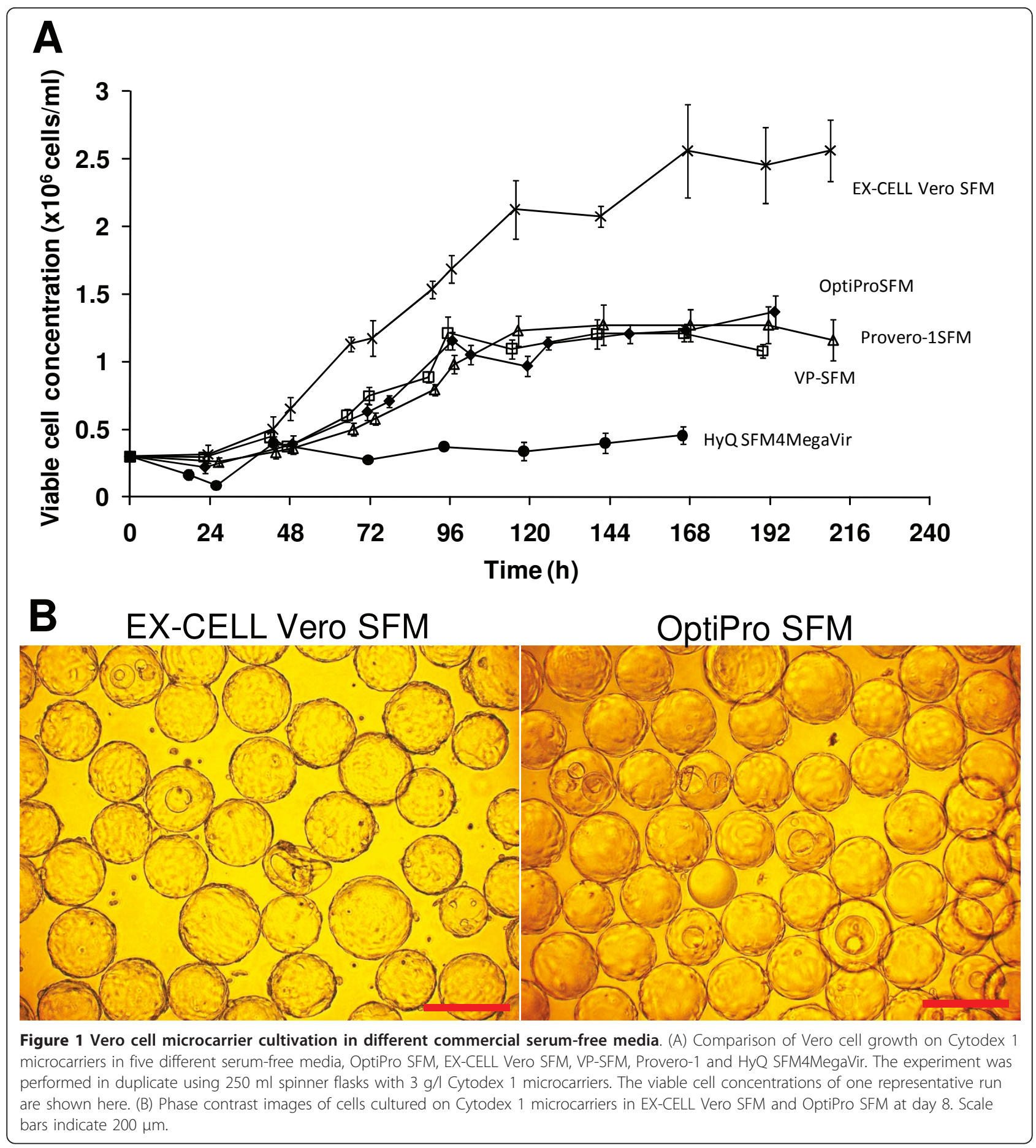

$90 \%$ on days 4 or 5 . Growth of Vero cells in EX-CELL Vero SFM was the highest achieving $2.6 \times 10^{6}$ cells $/ \mathrm{ml}$ (97\% viability) on day 7 .

Previous studies have reported that serum-free medium enriched with serum were able to achieve such high cell concentrations in batch cultivation of Vero cells when compared to serum-free media [47-49]. The difference in the maximum cell concentration reached was explained by the higher cell death rate in the serum-free medium, possibly caused by the lack of protective effect of serum, depletion of essential nutrient and accumulation of toxic metabolites [50]. To investigate whether this phenomenon can be replicated by providing nutrients and removing toxic metabolites for cells 
cultivated in OptiPro SFM, cell cultivation with medium exchanges was carried out (Figure 2). However, the higher cell density observed in EX-CELL Vero SFM was not attainable with this strategy. Comparing the cell morphology in these two media, a more compact cell monolayer was observed in EX-CELL Vero SFM when compared to cells cultured in OptiPro SFM (Figure 1B). Hence, the higher cell concentration in EX-CELL Vero SFM was not due to multilayer of cells, but a difference in cell morphology.
Comparing the maximum cell densities observed in this report with other studies involving Vero cell cultivation on Cytodex 1 using serum-free media, Souza et al. [41] obtained comparable maximum cell density of 1.6 $\times 10^{6}$ cells $/ \mathrm{ml}$ in VP-SFM, while Rourou et al. and Tiwari et al. $[39,40]$ reached $2.6 \times 10^{6}$ cells $/ \mathrm{ml}$ and 2.1 $\times 10^{6}$ cells $/ \mathrm{ml}$ respectively in the same media. The reason for these higher maximum cell densities was not clear in these reports. However, since the same Cytodex 1 concentration of $3.0 \mathrm{~g} / \mathrm{l}$ was used, we speculate that

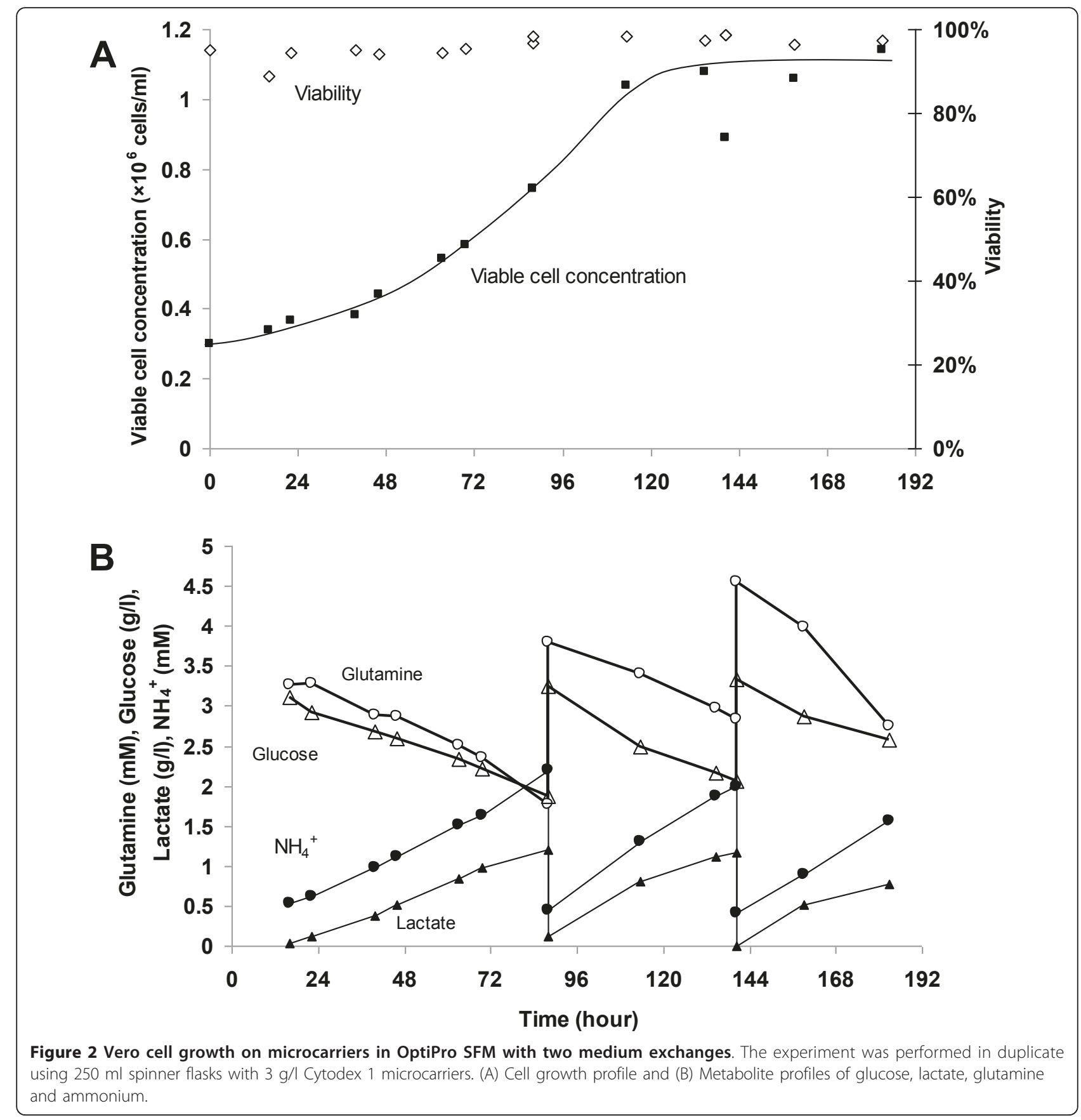


these may also be due to a more compact cell monolayer, similar to our observation in EX-CELL Vero SFM cultures. The difference in cell morphology may be greater in the former study [42] because an even higher maximum cell density of $5 \times 10^{6}$ cells $/ \mathrm{ml}$ on $3.0 \mathrm{~g} / \mathrm{l}$ Cytodex 1 was reported in perfusion mode. In contrast, Silva et al. [42] reported a maximum cell density of $1 \times$ $10^{6}$ cells $/ \mathrm{ml}$ for Vero cells cultivated in EX-CELL Vero SFM using the same microcarrier concentration. This may be due to a lack of adaptation from serum containing medium since the cells were directly seeded into EX-CELL Vero SFM for infection 24 h later. Other reports of Vero cultivation in different SFM typically achieved less than $2 \times 10^{6}$ cells/ml $[35,43,44,46]$, except one using a proprietary medium [45].

As higher maximum cell densities were observed in other studies using VP-SFM $[39,40]$, one possible explanation for the observed change in cell morphology may be differences in cell handling during adaptation to SFM. As such, relevant characteristics such as tumorigenicity of the cells should be investigated before these cells are used to produce clinical materials. Another perspective to investigate this phenomenon is to look at the available information on the components and formulation of these media: We observed higher starting glucose and amino acid contents in EX-CELL Vero SFM and VP-SFM compared to OptiPro SFM, as well as undefined plant hydrolysates and recombinant proteins. We speculate that these differences may also play an integral role in enabling the higher cell concentrations in EX-CELL Vero SFM and VP-SFM cultures.

Since viable cell yield in EX-CELL Vero SFM was highest, it was chosen for our subsequent studies. Vero cell cultivation in EX-CELL Vero SFM was scaled up in a $3 \mathrm{~L}$ stirred tank bioreactor for validation. The results are presented in Figure 3. Despite the longer lag phase, cell yield of $2.7 \times 10^{6}$ cells $/ \mathrm{ml}$ (93\% viability) were comparable to those achieved in spinner flask (Figure 1). 3.9 $\mathrm{g} / \mathrm{l}$ of glucose and $2.9 \mathrm{mM}$ of glutamine were consumed and $2.9 \mathrm{~g} / \mathrm{l}$ lactate and $2.2 \mathrm{mM}$ ammonium were produced by day 6 (Figure 3B) when peak cell density was reached. The maximal specific growth rate was calculated to be $0.019 \mathrm{~h}^{-1}$, which is similar to that of our spinner flask culture $\left(0.017 \mathrm{~h}^{-1}\right)$ and those from previous studies with other SFM $\left(0.026 \mathrm{~h}^{-1}\right.$ [48,50], 0.023-0.033 $\mathrm{h}^{-}$ 1 [39]).

\section{Parameters for Influenza infection: trypsin concentration, multiplicity of infection (MOI) and time-point of infection (TOI)}

Trypsin is essential for the replication of some Influenza virus strains. To assess the effect of trypsin concentration on the amplification of $\triangle \mathrm{NS} 1 \mathrm{H} 1 \mathrm{~N} 1$, we performed small scale infections of microcarrier cultures in 6-well suspension culture plates. Vero cells were first cultivated in $250 \mathrm{ml}$ spinner flask in EX-CELL Vero SFM. When the culture reached $2 \times 10^{6}$ cells $/ \mathrm{ml}$, cells were transferred into 6-well suspension culture plates for infections. The wells were supplemented with different trypsin concentrations of $3 \mu \mathrm{g} / \mathrm{ml}, 5 \mu \mathrm{g} / \mathrm{ml}$ and $10 \mu \mathrm{g} /$ $\mathrm{ml}$ in duplicates. To investigate the possibility of using lower trypsin concentrations by daily feeding, 2 sets of wells were supplemented with trypsin at $1 \mu \mathrm{g} / \mathrm{ml} /$ day and $2 \mu \mathrm{g} / \mathrm{ml} /$ day respectively. MOI of 0.01 and 0.001 were used in this experiment to concurrently assess the effect of this parameter on virus amplification. Samples were harvested 12 hourly and virus titres were determined by haemagglutination (HA) and TCID $_{50}$ assays (Figure 4).

Virus production with $1 \mu \mathrm{g} / \mathrm{ml} /$ day of trypsin yielded lower HA titres for both MOI tested, although peak TCID $_{50}$ titres were similar albeit at a later time-point for MOI of 0.001 . This suggests that $\triangle \mathrm{NS} 1 \mathrm{H} 1 \mathrm{~N} 1$ virus production was limited by trypsin at a concentration of $1 \mu \mathrm{g} / \mathrm{ml}$. On the other hand, virus production using 3 $\mu \mathrm{g} / \mathrm{ml}, 5 \mu \mathrm{g} / \mathrm{ml}$ and $10 \mu \mathrm{g} / \mathrm{ml}$ trypsin, as well as daily trypsin feed at $2 \mu \mathrm{g} / \mathrm{ml} /$ day, yielded high peak virus titres between 7.5 and $8.0 \log _{10} \mathrm{TCID}_{50} / \mathrm{ml}$ for both MOI tested. Since the assay has a standard deviation of $0.4 \log _{10} \mathrm{TCID}_{50} / \mathrm{ml}$, the peak virus titres with the above conditions were not significantly different. However, infection using $10 \mu \mathrm{g} / \mathrm{ml}$ trypsin resulted in higher virus titres at the $24 \mathrm{~h}$ time point for both MOI, implying a faster virus amplification process. Similar observations were also described in literature [27,35]. As live $\left(\mathrm{TCID}_{50}\right)$ virus titres were reported to decrease with time $[27,35]$, a faster virus amplification process with 10 $\mu \mathrm{g} / \mathrm{ml}$ trypsin is beneficial for the production of live attenuated virus vaccines such as $\triangle \mathrm{NS} 1 \mathrm{H} 1 \mathrm{~N} 1$. Hence $10 \mu \mathrm{g} / \mathrm{ml}$ trypsin and MOI of 0.001 (for lower amounts of virus inoculums during vaccine production) were used in the subsequent experiments.

For cell-based Influenza virus production, culture infection is typically performed at a time-point close to when the peak cell density is reached without timepoint of infection (TOI) studies [26-28,32,35]. However, varying TOI has been shown to increase titres of other viruses $[38,41]$. In addition to a difference in cell densities at the different TOI, the state of the cells at the different phases of cell culture may also affect virus production. To determine the effect of TOI for $\Delta$ NS1 H1N1 infection, 3 time-points at the late exponential to stationary phase were tested. Vero cells were first cultivated on microcarriers in spinner flask using the same condition as previously described. Figure 5A shows the average cell concentration measured from two spinner flasks. At days 5, 6, and 7, cells were transferred to 6well suspension culture plates and infected at MOI 

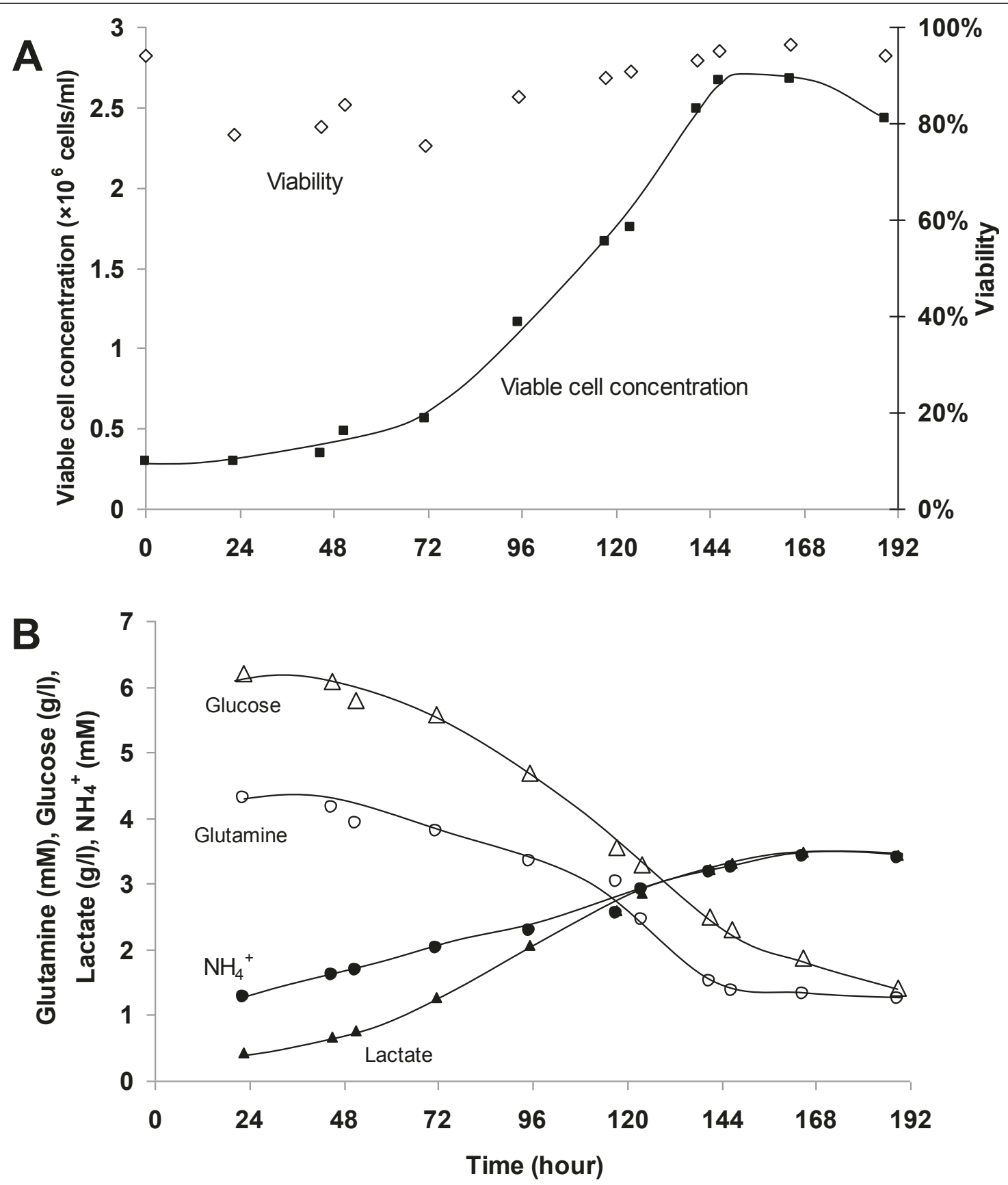

Figure 3 Cultivation of Vero cells on microcarriers in a $\mathbf{3}$ L stirred tank bioreactor using EX-CELL Vero SFM with $3 \mathrm{~g} / \mathrm{l}$ Cytodex $\mathbf{1}$. The experiment was performed in triplicate. (A) Cell growth profile and (B) Metabolite profiles of glucose, lactate, glutamine and ammonium.

0.001 with $10 \mu \mathrm{g} / \mathrm{ml}$ of trypsin. The peak virus titres, obtained $48 \mathrm{~h}$ post-infection in all the 6-well plates, are shown in Figure 5B.

The peak virus titres from the day 7 samples were slightly higher than those from other time-points. Day 7 is also when the peak cell density of $2.8 \times 10^{6}$ cells $/ \mathrm{ml}$ was reached. However, statistical analysis shows that the virus titres obtained in these three time points are not significantly different ( $\mathrm{p}$-value $>0.5$ ). This suggests that time-point of infection between the late exponential to stationary phases of cell growth, with the different cell densities from 2.1 to $2.8 \times 10^{6}$ cells $/ \mathrm{ml}$, does not significantly affect virus yield. The lack of increase in virus titres with infections at higher cell densities is also known as the "cell density effect". This was first observed study by Wood et al. [51] and later reported 


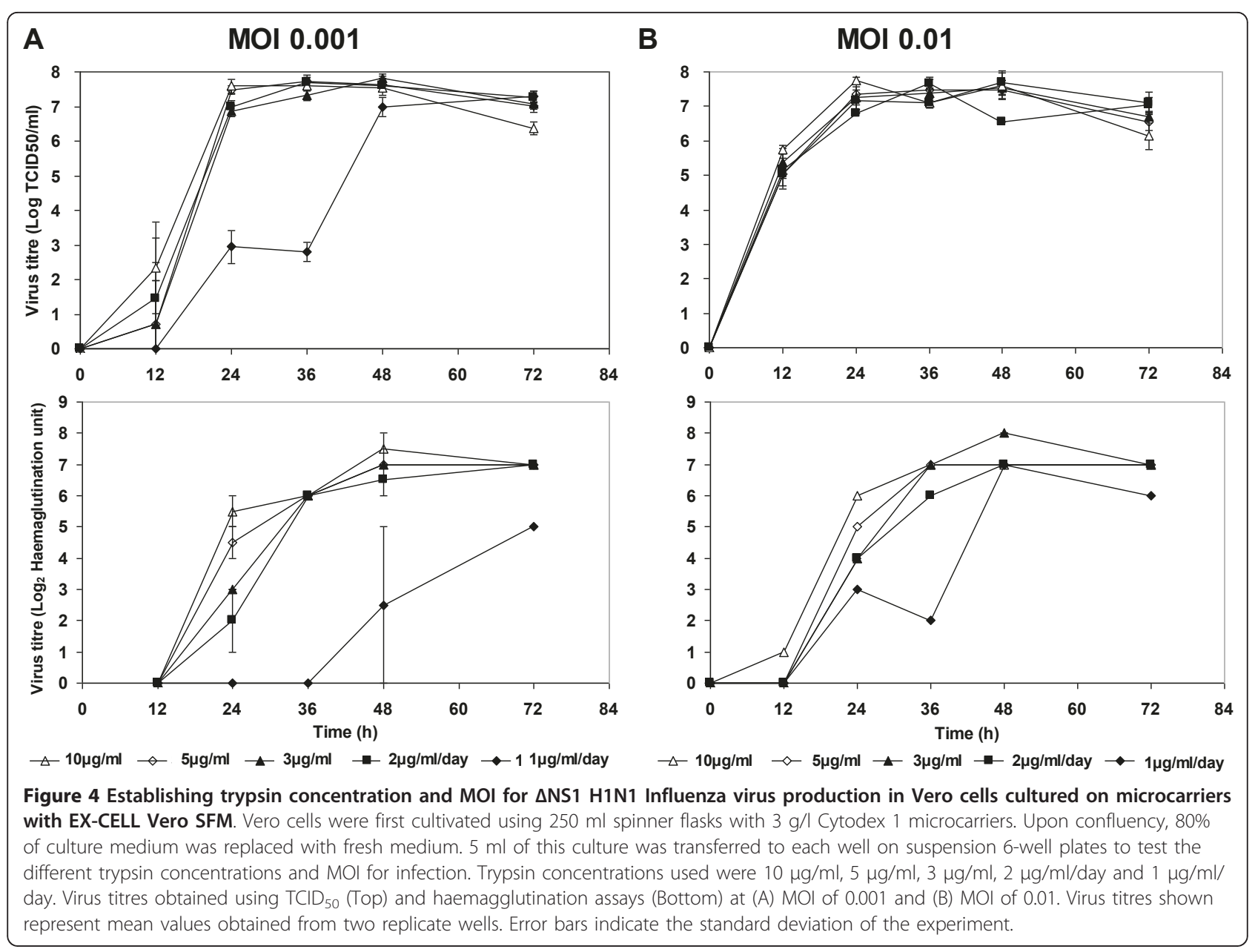

in other virus production system [39,52-55]. While nutrient limitation and unknown inhibitory factors generated during the process can account for most cases (adenovirus [52,53], Influenza [54], Retrovirus [55], Rabies virus [39]), this is not applicable here since culture medium was replaced with fresh medium during infection. As with other reports [56-59], more understanding on the virus replication mechanism is needed here to identify critical parameters.

\section{Production of $\triangle \mathrm{NS} 1$ and wild type H1N1 Influenza virus in bioreactor}

The propagation of $\triangle \mathrm{NS} 1 \mathrm{H} 1 \mathrm{~N} 1$ virus in bioreactor with EX-CELL Vero SFM containing Cytodex 1 is shown in Figure 6. Cells were infected with the virus when the cell concentration reached $2.3 \times 10^{6}$ cells $/ \mathrm{ml}$ on day 6 with MOI of 0.001 and trypsin concentration of $10 \mu \mathrm{g} / \mathrm{ml}$. The virus titres were monitored for 3 days. As shown in Figure $6 \mathrm{~A}$, upon infection viable cell concentration decreased rapidly which coincided with the increase in the virus titres. It reached the maximum of $8.3 \log _{10} \mathrm{TCID}_{50} / \mathrm{ml}$ and $5 \log _{2}$ haemagglutination unit (HAU) $30 \mathrm{~h}$ after infection. The $\mathrm{TCID}_{50}$ titre then steadily decreased from $48 \mathrm{~h}$ post-infection onwards, suggesting that there was degradation of live virus particles in the bioreactor. As shown in Figure 6B, the virus production trends also correlate with the trends observed in the consumptions of glucose and glutamine and the productions of lactate and ammonia. Infection using a MOI of 0.01 showed comparable peak virus titres (Figure 6C), in agreement with our previous observations in small scale infections.

To compare $\Delta \mathrm{NS} 1 \mathrm{H} 1 \mathrm{~N} 1$ virus production to the wild type Influenza virus, we performed bioreactor runs using the same media, identical bioreactor and infection parameters with the wild type Influenza A virus IVR116, NIBSC code 06/108 corresponding to our model $\triangle \mathrm{NS1} H 1 \mathrm{~N} 1$ virus. The cell growth and the subsequent infection in EX-CELL Vero SFM are shown in Figure 7A. In metabolite profiles shown in Figure 7B, more glucose and glutamine were consumed and consequently more lactate was produced when compared to the profiles of $\triangle \mathrm{NS} 1 \mathrm{H} 1 \mathrm{~N} 1$ in Figure $6 \mathrm{~B}$. The wild type virus titre of $10 \log _{10} \mathrm{TCID}_{50} / \mathrm{ml}$ and $9 \log _{2} \mathrm{HAU}$ was achieved in 24 hours. 

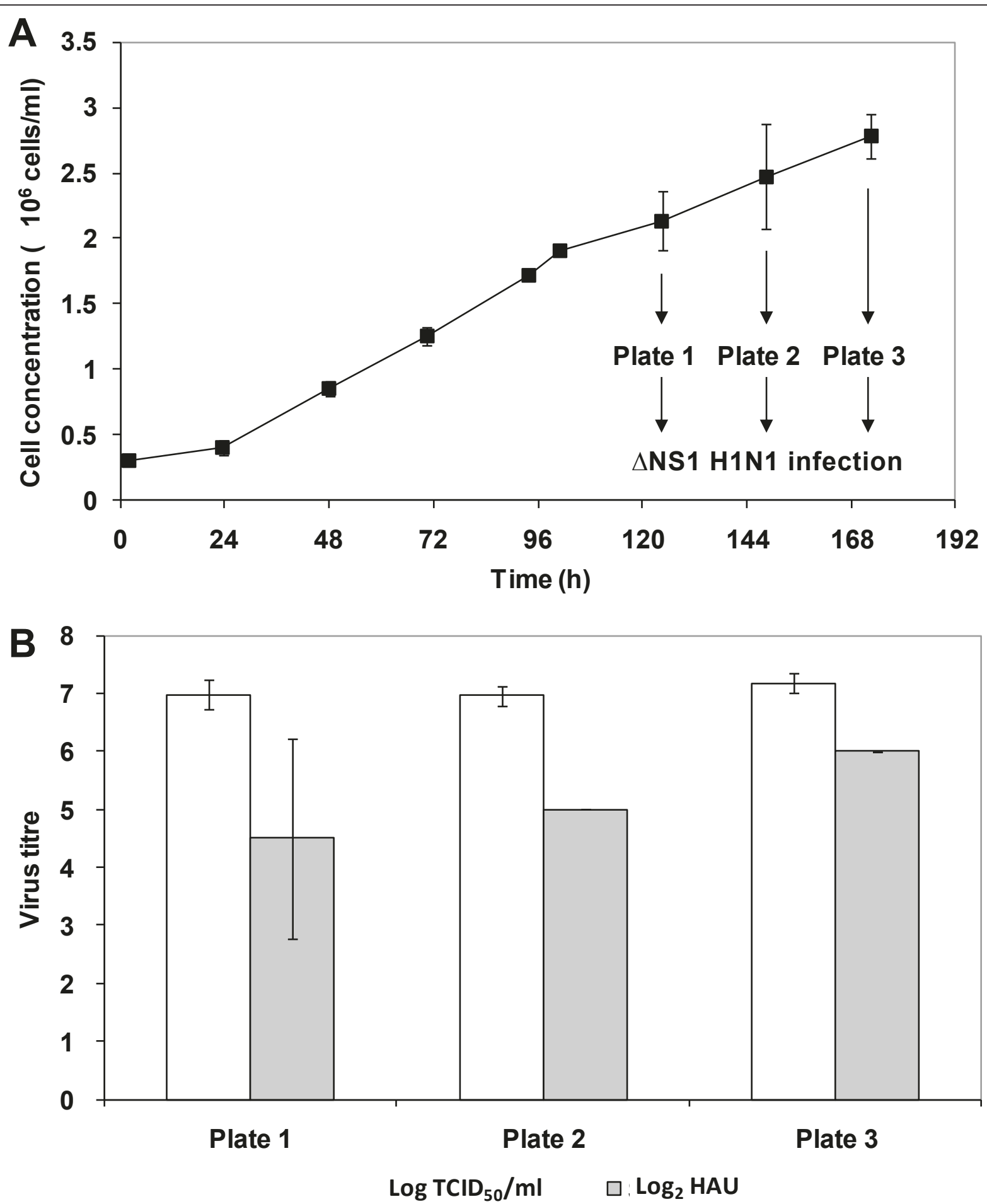

Figure 5 Establishing time-point of infection (TOI) for $\triangle \mathrm{NS} 1 \mathrm{H} 1 \mathrm{~N} 1$ Influenza virus production in Vero cells cultured on microcarriers with EX-CELL Vero SFM. (A) Growth curve of Vero cells cultivated using $250 \mathrm{ml}$ spinner flasks with $3 \mathrm{~g} / \mathrm{l}$ Cytodex 1 microcarriers. Cells were infected at day 5, day 6 and day 7 as depicted, by transferring $5 \mathrm{ml}$ of the culture to each well on suspension 6 -well plates. (B) Virus titre was measured at 48 hours post-infection for all TOl. Each bar represents the mean of the virus titres yielded from two runs using $\mathrm{MOI}$ of 0.001 . The error bars indicate the standard deviation of the two runs. 

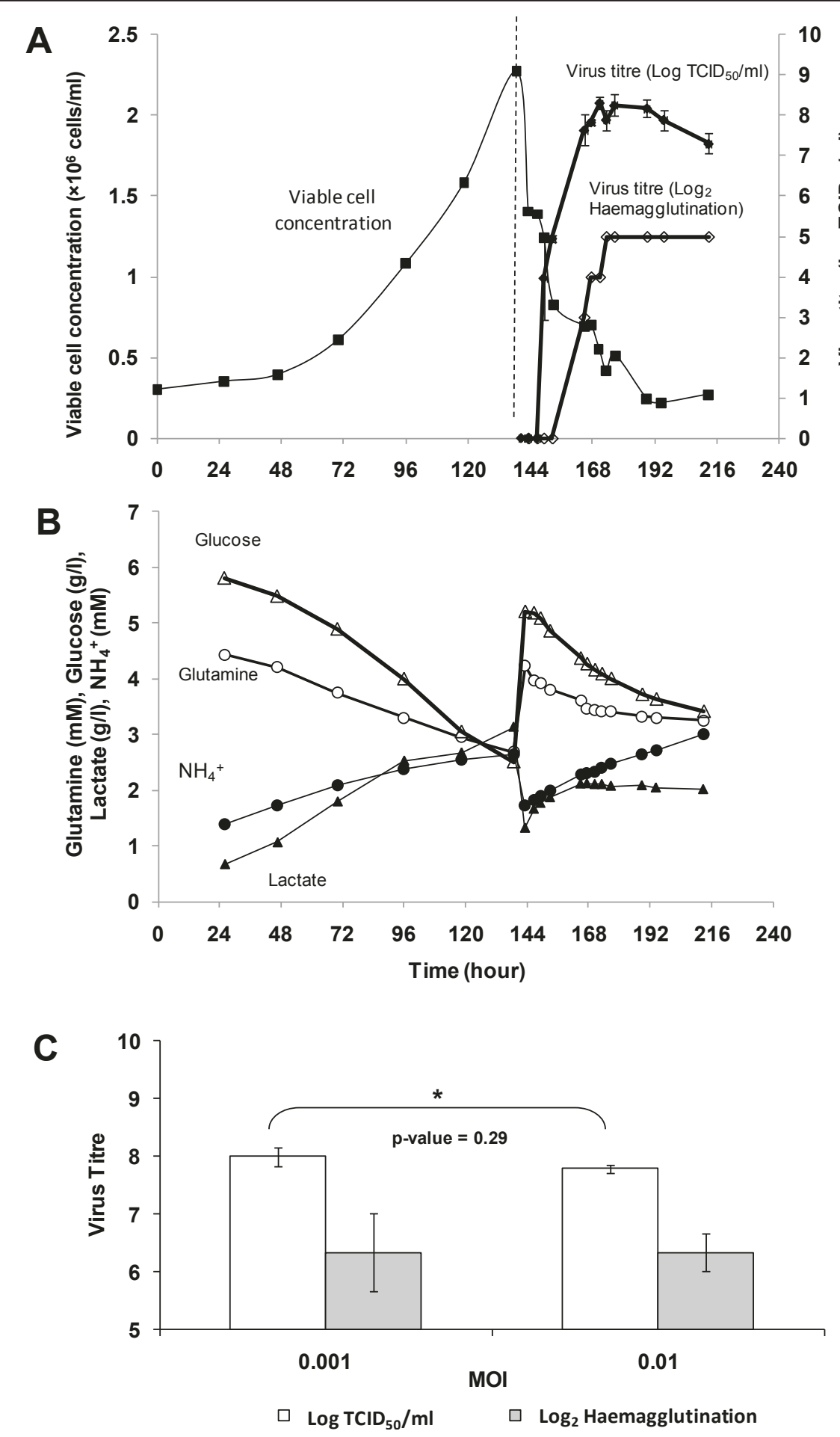

Figure 6 Cell cultivation and $\triangle$ NS1 H1N1 Influenza virus amplification in 3 L stirred tank bioreactor using EX-CELL Vero SFM with 3 g/l Cytodex 1, MOI of 0.001 and trypsin concentration of $10 \mu \mathrm{g} / \mathrm{ml}$. (A) Cell growth profile and virus amplification of representative bioreactor run. Error bars indicate the standard error of triplicate measurements. (B) Metabolite profiles of glucose, lactate, glutamine and ammonium, before and after infection. (C) Comparison of max virus titres between infection at M.O.I 0.001 and 0.01 carried out in 3 L bioreactor scale. Log 2 $\mathrm{HAU}$ is represented as filled bars and non-filled bar indicates virus titre in $\log _{10} T C \mathrm{D}_{50} / \mathrm{ml}$. Error bars indicate the standard deviation of triplicate bioreactor runs. 


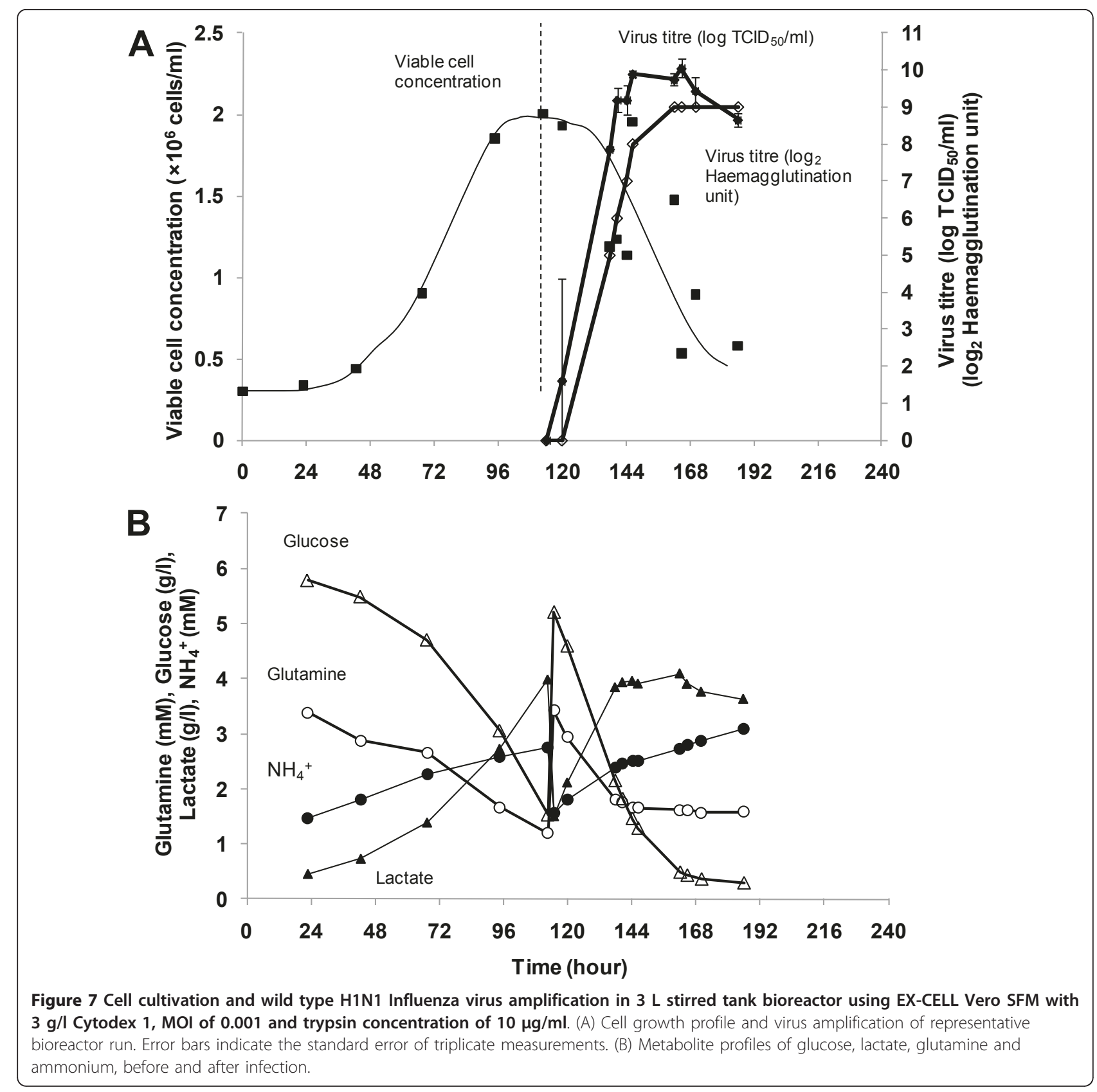

The bioreactor processes for the production of $\Delta \mathrm{NS} 1$ $\mathrm{H} 1 \mathrm{~N} 1$ and wild type $\mathrm{H} 1 \mathrm{~N} 1$ viruses were repeated at least twice to obtain average virus titres of $8.1 \pm 0.30$ $\log _{10} \mathrm{TCID}_{50} / \mathrm{ml}$ and $6.4 \pm 0.40 \log _{2} \mathrm{HAU}$, and $9.6 \pm$ $0.56 \log _{10} \mathrm{TCID}_{50} / \mathrm{ml}$ and $8.5 \pm 0.50 \log _{2}$ HAU respectively. The virus titres achieved in the wild type strain is $1.5 \log _{10} \mathrm{TCID}_{50} / \mathrm{ml}$ higher and $2.1 \log _{2}$ HAU significantly higher $(\mathrm{P}<0.05)$ than $\triangle \mathrm{NS} 1 \mathrm{H} 1 \mathrm{~N} 1$ using EXCELL Vero SFM. We speculate that this may be largely due to differences in the viruses, especially the NS1 deletion, since it was known that the NS1 protein in infected cells interacts with host cell gene expression and cellular protein regulation including interferon mediated antiviral responses $[11,60,61]$. Although the use of interferon deficient Vero cells allows us to circumvent the cellular antiviral responses $[8,16]$, recent reports suggest that the Influenza A NS1 protein is also involved in anti-apoptotic signaling through Phosphatidylinositol-3-kinase (PI3K) pathway [62-64]. In agreement with literature, we observed that the viable cell concentration remained relatively unchanged during the first $24 \mathrm{~h}$ of the wild type virus infection and only started to decline when peak virus titre was reached (Figure 7A). In contrast, a more rapid decrease in viable 
cell concentrations upon infection with $\triangle \mathrm{NS1}$ strain was observed (Figure 6A). $\triangle \mathrm{NS1} \mathrm{H} 1 \mathrm{~N} 1$ virus infected cells also showed more prominent cell death with earlier complete cell detachment from the microcarriers (Figure 8). We therefore believe that virus titre improvements may be possible via preventing apoptosis. A recent study by Seitz et al. [65] demonstrated the possibility of this approach with transient expressed NS1 gene in MDCK cells to enhance replication of an influenza virus lacking NS1.
Comparing our observed titres of the wild type H1N1 virus with literature, haemagglutination titre obtained in this study was 0.5 to $1 \log _{2}$ higher than other Vero bioreactor processes producing Influenza virus using serum-free or serum-containing media [33,35]. However this may not be significant considering haemagglutination activity varied between strains. In addition, these reports used avian erythrocytes for HA assay while we have used human erythrocytes. Our observed titres are also comparable to those reported in MDCK bioreactor

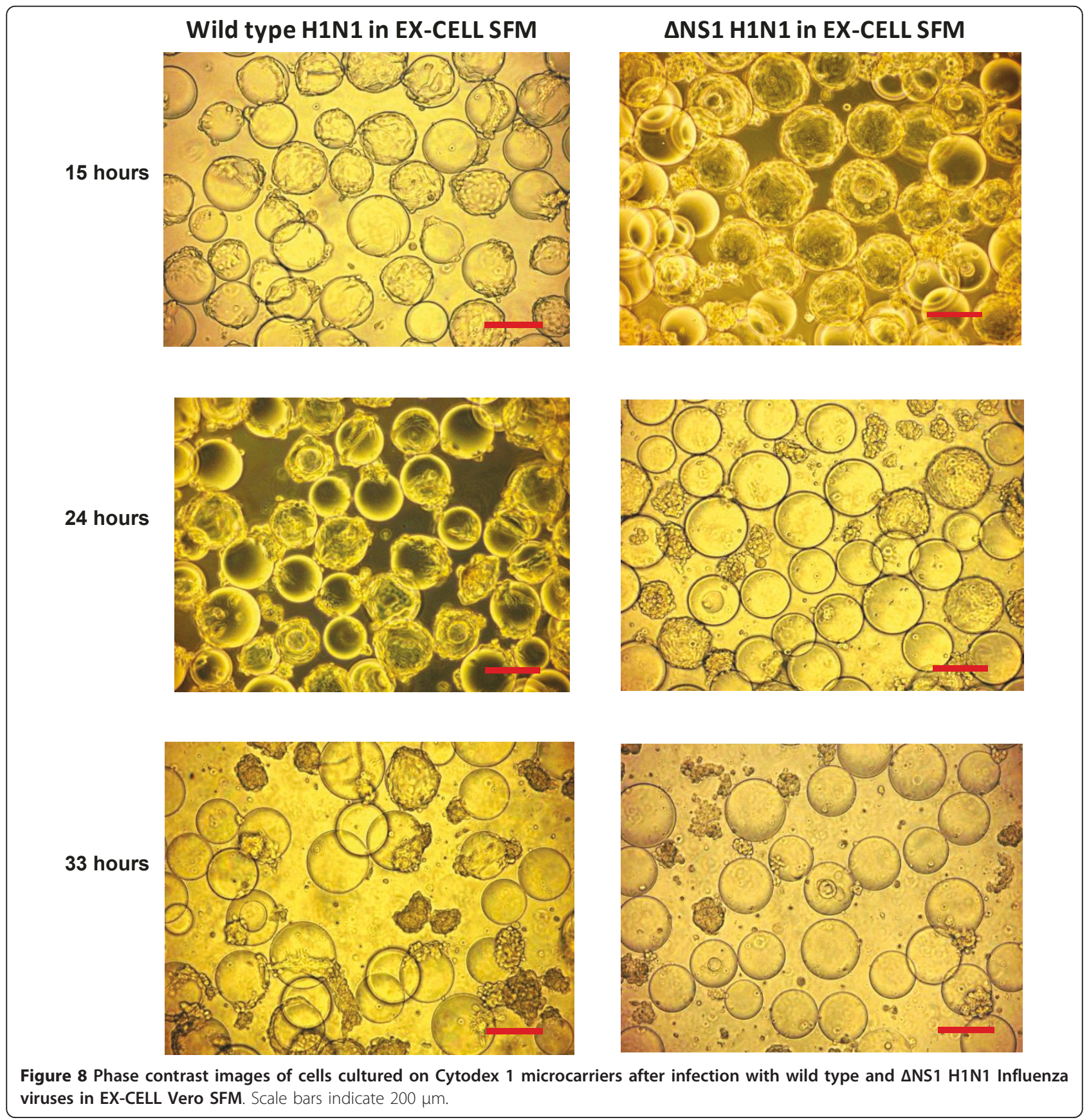


processes producing Influenza viruses (2.4 to $3.3 \log _{10}$ $\mathrm{HA} / 100 \mu \mathrm{l}[26,27,35], 7.7 \log _{10} \mathrm{TCID}_{50} / \mathrm{ml}$ [27], and 8.5 to $\left.10 \log _{10} \mathrm{EID}_{50} / \mathrm{ml}[28]\right)$.

\section{Comparison of $\triangle \mathrm{NS} 1$ and wild type H1N1 Influenza virus production using EX-CELL Vero SFM and OptiPro SFM}

As the $\triangle \mathrm{NS} 1$ and wild type H1N1 Influenza virus titres were significantly different in EX-CELL Vero SFM, we wanted to find out whether this is also true in other SFM. In addition, we wanted to investigate whether the "cell density effect" can be observed when we compare EX-CELL Vero SFM with another serum-free medium that gives a lower maximum cell density. We thus performed the bioreactor virus production using OptiPro SFM for this comparison.

Using OptiPro SFM, the average virus titres of $\triangle \mathrm{NS} 1$ $\mathrm{H} 1 \mathrm{~N} 1$ and wild type $\mathrm{H} 1 \mathrm{~N} 1$ viruses were $8.0 \pm 0.05$ $\log _{10} \mathrm{TCID}_{50} / \mathrm{ml}$ and $6.0 \pm 0.41 \log _{2} \mathrm{HAU}$, and $8.7 \pm$ $0.11 \log _{10} \mathrm{TCID}_{50} / \mathrm{ml}$ and $5.5 \pm 0.50 \log _{2}$ HAU respectively. Similar to the virus production process using EXCELL Vero SFM, a higher $\mathrm{TCID}_{50}$ virus titre was obtained with the wild type virus compared to the $\triangle \mathrm{NS} 1 \mathrm{H} 1 \mathrm{~N} 1$ virus, although the difference was less distinct than the results with EX-CELL Vero SFM and the haemagglutination titres were not significantly different (Figure 9). This confirms our previous observation in EX-CELL Vero SFM, that the inherent differences in the viruses, such as the deletion of the NS1 gene, may be the primary factor resulting in the different virus titres. We speculate that the difference is less distinct in OptiPro SFM due to the lower maximum cell density and peak virus titres, as discussed below.
Comparing the peak virus titres of the wild type virus in EX-CELL Vero SFM and OptiPro SFM, EX-CELL Vero SFM gave a $1 \log _{10} \mathrm{TCID}_{50} / \mathrm{ml}$ higher titre, while that of the $\triangle \mathrm{NS} 1 \mathrm{H} 1 \mathrm{~N} 1$ virus were similar (Figure 9). As cell concentration in EX-CELL Vero SFM was almost twice that of OptiPro SFM, this suggests that the higher cell density may be beneficial to increasing virus titre of the wild type H1N1 Influenza virus, contrary to the "cell density effect". On the other hand, the higher cell density achieved using EX-CELL Vero SFM did not contribute to a higher virus titre for the $\triangle \mathrm{NS} 1 \mathrm{H} 1 \mathrm{~N} 1$ virus, validating our previous observation in TOI studies with the same virus (Figure 5). This suggests that the "cell density effect" observed for the $\triangle \mathrm{NS} 1 \mathrm{H} 1 \mathrm{~N} 1$ virus may be due to differences between this virus and the wild type virus, and one obvious difference between these two viruses is the NS1 deletion. The absence of this gene may have allowed the virus to trigger apoptotic pathways in the Vero cells to limit virus yield, as discussed previously in this report.

To validate that the observed "cell density effect" is not due to changes in culture medium during virus production, we analyzed the metabolite profiles of these cultures. The analyses of glucose, glutamine and amino acids (data not shown) have not revealed any shortage during the virus production in the two SFM and two viruses tested. Ammonium concentrations were below $20 \mathrm{mM}$, while lactate concentrations were above $0.8 \mathrm{~g} / \mathrm{l}$ prior to virus infection with both EX-CELL Vero SFM and OptiPro SFM. As it has been reported in MDCK cells that lactate concentration of $8 \mathrm{mM}$ (or $0.7 \mathrm{~g} / \mathrm{l}$ ) at the time point for infection can reduce haemagglutination unit by a factor of two [66]

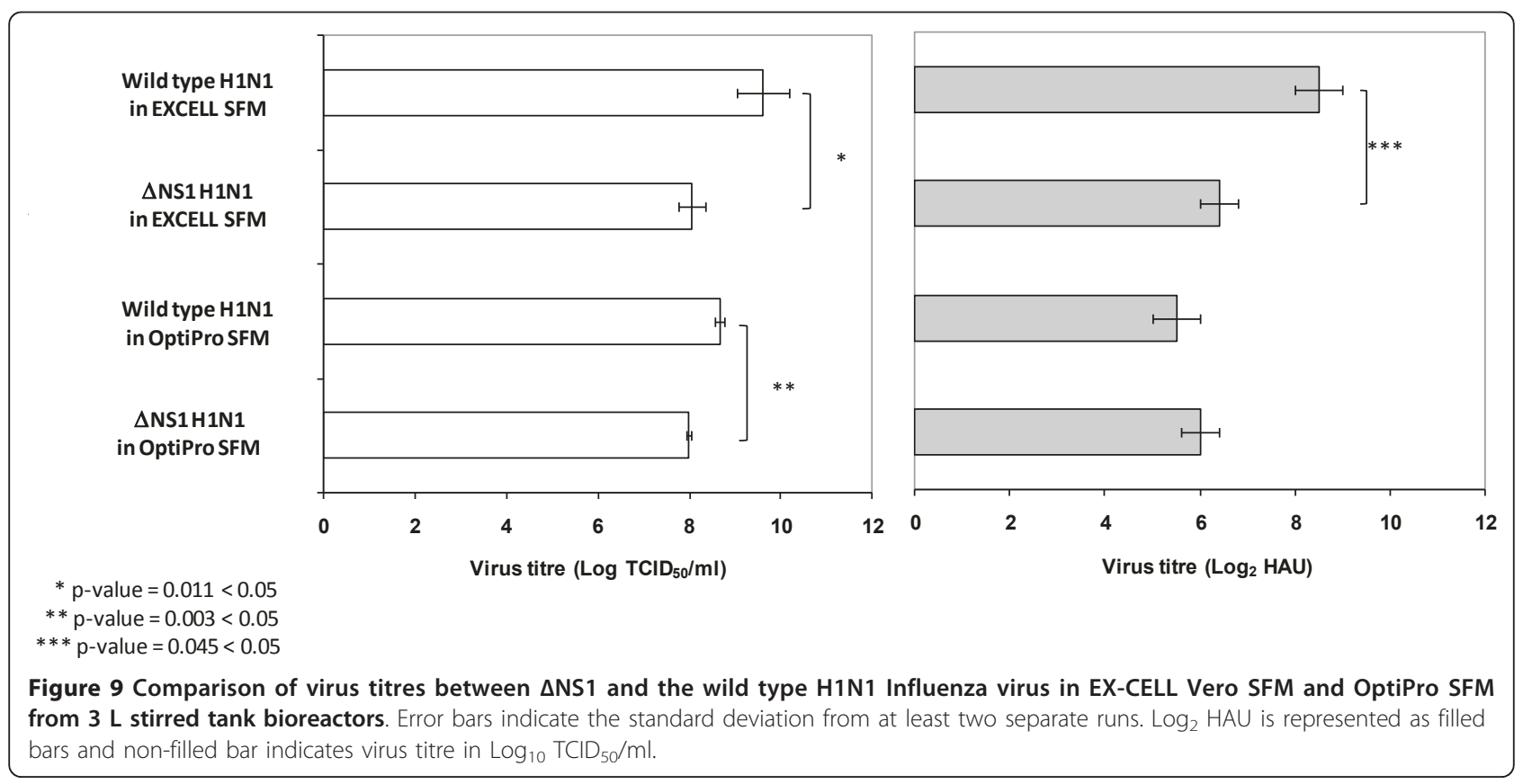


and the addition of ammonium chloride to $20 \mathrm{mM}$ was reported to block infection [67-69], the high lactate level we observed may have some influences to limit the maximum virus titres achieved with these medium. On the other hand, a higher lactate level was observed in the wild type virus production with $3.9 \mathrm{~g} / \mathrm{l}$ generated $24 \mathrm{~h}$ postinfection. Hence it is unclear to what extent the virus production using Vero cells can be affected by lactate accumulation without further experiments.

\section{Conclusions}

We have compared five commercially available SFM for the microcarrier based cultivation of Vero cells. In addition, we described for the first time the production of Influenza viruses using Vero cells in commercially available animal component-free, serum-free medium, and a potentially scalable stirred tank bioreactor process for the production of $\triangle \mathrm{NS} 1 \mathrm{H} 1 \mathrm{~N} 1$ virus. Comparing the production of the $\triangle \mathrm{NS} 1 \mathrm{H} 1 \mathrm{~N} 1$ virus to that of the corresponding wild-type strain, we showed that titres of $\triangle \mathrm{NS} 1 \mathrm{H} 1 \mathrm{~N} 1$ virus were lower than that of the wildtype, and postulated that this may be a result of earlier Vero host cell death due to the NS1 deletion.

\section{Methods}

\section{Preparation of cell line, virus strain, trypsin stock and microcarriers}

Vero cells (ATCC CCL-81) from a master cell bank at passage 126 was thawed into DMEM (Invitrogen, Grand Island, NY) $+10 \%(\mathrm{v} / \mathrm{v})$ fetal bovine serum (FBS) (Invitrogen) and passaged three times before stepwise adaptation to different serum-free media (SFM) to form working cell banks. The SFM used were OptiPro SFM (Invitrogen, Grand Island, NY, Cat. No. 12309-019), VPSFM (Invitrogen, Cat. No. 11681-020), EX-CELL Vero SFM (SAFC Biosciences, Lenexa, KS, Cat. No. 14585), Provero-1 (Lonza, Belgium, Cat. No. BE-02-030Q) and HyQ SFM4MegaVir (HyClone, Logan, UT, Cat. No. SH30522.01), supplemented according to manufacturers' instructions. Cells were subsequently thawed from these working cell banks and passaged in tissue culture flasks (T-flasks) in their respective media for 2 or more passages prior to use. Passage numbers of cells used for experiments were less than 150. Cells cultures were incubated in $37^{\circ} \mathrm{C} / 5 \% \mathrm{CO}_{2}$ humidified incubators (Sanyo, Japan).

Influenza A/New Caledonia/20/99(H1N1)-like virus, with NS1 deletion ( $\triangle \mathrm{NS} 1$ ) was provided by Avir Green Hills Biotechnology. The corresponding wild type Influenza A virus was obtained from NIBSC (Influenza IVR116, NIBSC code 06/108). Working banks of the viruses were created by amplifying the virus using Vero cells cultivated in OptiPro SFM (Invitrogen) in T-flasks or Cell Factories (Nunc, Denmark). While the $\Delta$ NS1 H1N1 virus was already adapted to Vero cells, the wild type virus was propagated using Vero cells for 6 passages prior to the creation of the working bank. Virus titres of the $\triangle \mathrm{NS} 1$ and wild type $\mathrm{H} 1 \mathrm{~N} 1$ working banks were 7.1 to $7.3 \log _{10} \mathrm{TCID} 50 / \mathrm{ml}$ and 4 to $5 \log _{2} \mathrm{HAU}$, and 9.0 $\log _{10} \mathrm{TCID} 50 / \mathrm{ml}$ and $6.5 \log _{2}$ HAU respectively, quantified as described below.

Porcine trypsin used for Influenza virus activation (Sigma-Aldrich, St. Louis, MO, Cat. No. T5266, 1500 BAEE unit/mg) was dissolved in deionized water and sterile filtered to make a $5 \mathrm{mg} / \mathrm{ml}$ stock solution. This stock solution was aliquoted and stored in $-20^{\circ} \mathrm{C}$ freezer. Trypsin aliquots were thawed once for experiments.

Cytodex 1 microcarriers (GE Healthcare, Sweden, Cat. No. 17-0448-01) were hydrated and sterilized in a glass bottle pre-coated with Sigmacote ${ }^{\circledR}$ (Sigma-Aldrich, Cat. No. SL2) according to manufacturers' instructions.

\section{Quantification of virus titres and monitoring of cell cultivation process}

Virus titres were quantified using the haemagglutination assay [70] and tissue culture infectious dose ( $\left.\mathrm{TCID}_{50}\right)$ assay [53]. For the haemagglutination assay, 4\% human erythrocytes (Siemens Healthcare Diagnostics, Germany) were diluted 8-fold in Dulbecco's phosphate buffer solution (PBS, Invitrogen, Cat. No. 14190-250) to obtain a $0.5 \%$ cell suspension. $50 \mu \mathrm{l}$ of this $0.5 \%$ cell suspension was then added to an equal volume of virus and control samples in 2-fold serial dilutions. Haemagglutination unit (HAU) of a virus sample was read as the highest dilution in which haemagglutination was observed.

$\mathrm{TCID}_{50}$ assay was performed by adding $50 \mu \mathrm{l}$ of 10 fold serially diluted virus samples to Vero cells cultivated on 96 well plates using OptiPro SFM (Invitrogen) supplemented with $5 \mu \mathrm{g} / \mathrm{ml}$ porcine trypsin (SigmaAldrich). The assay was carried out in triplicate sets, each consisting of 6 wells per diluted virus sample. $\mathrm{TCID}_{50}$ titres were calculated according to the formula of Reed and Muench [71]. As the dose for attenuated influenza virus vaccine in clinical studies is measured based on $\mathrm{TCID}_{50}$ assay [72,73], the comparisons of virus titres in our report were predominantly based on $\mathrm{TCID}_{50}$ instead of haemagglutination assay.

Cell cultivation process was monitored by measuring total cell density, viable cell density and key metabolite concentrations. Total cell density was determined with crystal violet nuclei staining. Briefly, a $500 \mu \mathrm{l}$ aliquot of cell culture sample was treated with an equal volume of $0.01 \%(\mathrm{w} / \mathrm{v})$ crystal violet (Sigma-Aldrich) in $0.1 \mathrm{M}$ citric acid solution and incubated for 30-45 minutes at $37^{\circ} \mathrm{C}$. The released nuclei from the cells were then counted using a hemacytometer. To determine viable cell density, we first observed that cells attached to the microcarriers were mostly viable with cell viability greater 
than $90 \%$ regardless of the stage of cell cultivation (data not shown). Based on this observation, Trypan blue cell exclusion method was used to obtain the density of non-viable cells that were not attached to microcarriers. Viable cell density was then estimated by deducting this from the total cell density measured with crystal violet nuclei staining.

Concentrations of key metabolites (glutamine, glucose, lactate and ammonium) in cell culture supernatants were analyzed using BioProfile 100 Plus (Nova Biomedical, Waltham, MA) as per manufacturer's instructions. Virus-containing samples were deactivated by heating in a $60^{\circ} \mathrm{C}$ water bath for 30 minutes prior to analysis.

\section{Cell cultivation and virus infection in spinner flasks}

$250 \mathrm{ml}$ spinner flasks (Bellco, Vineland, NJ) were coated with Sigmacote (Sigma-Aldrich) according to manufacturer's instructions. Vero cells were seeded into the spinner flasks at $6 \times 10^{5}$ cells $/ \mathrm{ml}$ in $125 \mathrm{ml}$ medium containing $6 \mathrm{mg} / \mathrm{ml}$ of hydrated Cytodex 1 microcarriers. Mixing in the spinner flasks was performed using a magnetic stirrer platform (Cellgro Type 45600, Thermolyne, Dubuque, IA) which rotates the magnetic microcarrier paddle impeller (Bellco, Cat No. 196530100) inside the flasks. The spinner flasks were stirred at $40 \mathrm{rpm}$ inside a $37^{\circ} \mathrm{C} / 5 \% \mathrm{CO}_{2}$ humidified incubator. Surface aeration was allowed by loosening the cap on one arm of the spinner flask. After $24 \mathrm{~h}$, the stirring speed was increased to $60 \mathrm{rpm}$, and the culture volume was increased to $250 \mathrm{ml}$ by addition of fresh medium. This results in cell and microcarrier concentrations of 3 $\times 10^{5}$ cells $/ \mathrm{ml}$ and $3 \mathrm{mg} / \mathrm{ml}$ respectively.

Prior to influenza virus infection, approximate $80 \%$ of the culture medium was exchanged. Influenza virus at predetermined MOI and trypsin were added to the spinner flask together with fresh medium. Stirring speed was then maintained at $60 \mathrm{rpm}$.

To determine the conditions for infection, cells were first cultivated on microcarriers in the spinner flasks as described above. At various stages of cultivation, the cells were transferred to suspension 6-well plates (Greiner Bio-One, Cat no. 657102) with $5 \mathrm{ml}$ culture volume per well. The well was incubated in $37^{\circ} \mathrm{C} / 5 \% \mathrm{CO}_{2}$ humidified incubators (Sanyo, Japan) on orbital shaker agitated at speed of $100 \mathrm{rpm}$. Different virus infection conditions, namely time of infection, trypsin concentration, and MOI, were tested in this format.

\section{Cell cultivation and virus infection in $3 \mathrm{~L}$ bioreactor}

$3 \mathrm{~L}$ bioreactor (Applikon, Netherlands) was coated with Sigmacote ${ }^{\circledR}$ (Sigma-Aldrich) and sterilized according to manufacturer's instructions. The bioreactor settings for experiments were as follows: culture temperature was set at $37^{\circ} \mathrm{C}$; maximum flow rate for
$\mathrm{O}_{2}$ and $\mathrm{CO}_{2}$ were set at $10 \mathrm{ml} / \mathrm{min}$; dissolved oxygen (DO) was set at $40 \%$ saturated air concentration; initial stirring speed was $60 \mathrm{rpm}$; initial $\mathrm{pH}$ were 7.1 and 7.3 for EX-CELL Vero SFM and OptiPro SFM respectively. Vero cells were seeded at $6 \times 10^{5}$ cells $/ \mathrm{ml}$ in $750 \mathrm{ml}$ medium with a microcarrier density of $6 \mathrm{mg} / \mathrm{ml}$. At 6 $\mathrm{h}$ post-seeding, the $\mathrm{pH}$ and stirring speed were changed to 7.2 and $100 \mathrm{rpm}$ respectively, as most cells were attached to the microcarriers. At $24 \mathrm{~h}$ post-seeding, the culture volume was increased to $1.5 \mathrm{~L}$ by adding fresh medium, to result in cell and microcarrier concentrations of $3 \times 10^{5}$ cells $/ \mathrm{ml}$ and $3 \mathrm{mg} / \mathrm{ml}$ respectively.

Influenza virus infection in bioreactor is similar to that in spinner flasks. $80 \%$ of the culture medium was first exchanged with fresh medium. Influenza virus at predetermined MOI and trypsin were then added to the bioreactor together with fresh medium. For infection in OptiPro SFM, $5 \mu \mathrm{g} / \mathrm{ml}$ trypsin was used, and the cells were infected at MOI 0.001 and 0.01 at cell concentrations of $1.2-1.4 \times 10^{6}$ cells $/ \mathrm{ml}$. The bioreactor settings remained unchanged.

\section{Statistical analysis}

Statistical analysis was carried out using two-tailed student's t-tests assuming equal variance with replications. $P$ values less than 0.05 were considered significant.

\section{Acknowledgements}

The authors thank Dr Kim Do Yun for his critical review of this paper. This work was supported by the Biomedical Research Council of A*STAR (Agency for Science, Technology and Research), Singapore, and Avir Green Hills Biotechnology, Austria.

\section{Author details}

${ }^{1}$ Bioprocessing Technology Institute, Agency for Science, Technology and Research (A*STAR), 20 Biopolis Way, \#06-01, Centros, Singapore 138668,

Singapore. ${ }^{2}$ Avir Green Hills Biotechnology, Forsthausgasse 11, 1200 Vienna, Austria.

\section{Authors' contributions}

AC participated in the design of the study, performed the statistical analysis and drafted the manuscript. SLP carried out the virus quantifications and cell culture studies, and participated in equipment set up and material

preparations. CD participated in the design of the study, in equipment set up and in parallel experiment verification (not presented). ER participated in the design of the study, in equipment set up and material preparations. MLY participated in the virus quantifications and cell culture studies, and in equipment set up and material preparations. SKN conceived the study, participated in its design and coordination, and drafted the manuscript. All authors read and approved this final manuscript.

Received: 9 May 2011 Accepted: 11 August 2011 Published: 11 August 2011

\section{References}

1. Poland GA, Jacobson RM, Targonski PV: Avian and pandemic influenza: An overview. Vaccine 2007, 25:3057-3061.

2. Kendal AP, Maassab HF, Alexandrova Gl, Ghendon YZ: Development of cold-adapted recombinant live, attenuated influenza A vaccines in the U.S.A. and U.S.S.R. Antivir Res 1982, 1(6):339-365. 
3. ADIS: Influenza Virus Vaccine Live Intranasal - Medlmmune Vaccines: CAIV-T, Influenza Vaccine Live Intranasal. Drugs R D 2003, 4(5):312-319.

4. Maassab HF, Bryant ML: The development of live attenuated coldadapted influenza virus vaccine for humans. Rev Med Virol 1999, 9:237-244

5. Belshe R, Lee M-S, Walker RE, Stoddard J, Mendelman PM: Safety, immunogenicity and efficacy of intranasal, live attenuated influenza vaccine. Expert Rev Vaccines 2004, 3(6):643-654.

6. Richt JA, García-Sastre A: Attenuated influenza virus vaccines with modified NS1 proteins. Curr Top Microbiol Immunol 2009, 333:177-195.

7. Treanor JJ, Kotloff K, Betts RF, Belshe R, Newman F, lacuzio D, Wittes J, Bryant M: Evaluation of trivalent, live, cold-adapted (CAIV-T) and inactivated (TIV) influenza vaccines in prevention of virus infection and illness following challenge of adults with wild-type influenza $A(H 1 N 1)$, A (H3N2), and B viruses. Vaccine 1999, 18(9-10):899-906.

8. García-Sastre A, Egorov A, Matassov D, Brandt S, Levy DE, Durbin JE, Palese P, Muster T: Influenza A Virus Lacking the NS1 Gene Replicates in Interferon-Deficient Systems. Virology 1998, 252(2):324-330.

9. Hai R, Martínez-Sobrido L, Fraser KA, Ayllon J, García-Sastre A, Palese P. Influenza B Virus NS1-Truncated Mutants: Live-Attenuated Vaccine Approach. J Virol 2008, 82(21):10580-10590.

10. Steel J, Lowen AC, Pena L, Angel M, Solórzano A, Albrecht R, Perez DR, García-Sastre A, Palese P: Live attenuated influenza viruses containing NS1 truncations as vaccine candidates against $\mathrm{H} 5 \mathrm{~N} 1$ highly pathogenic avian influenza. J Virol 2009, 83(4):1742-1753.

11. Talon J, Salvatore M, O'Neill RE, Nakaya Y, Zheng H, Muster T, GarcíaSastre A, Palese P: Influenza A and B viruses expressing altered NS1 proteins: A vaccine approach. Proc Natl Acad Sci USA 2000, 97(8):4309-4314

12. Wacheck V, Egorov A, Groiss F, Pfeiffer A, Fuereder T, Hoeflmayer D, Kundi M, Popow-Kraupp T, Redlberger-Fritz M, Mueller CA, et al: A Novel Type of Influenza Vaccine: Safety and Immunogenicity of ReplicationDeficient Influenza Virus Created by Deletion of the Interferon Antagonist NS1. J Infect Dis 2010, 201:354-362.

13. Kochs G, García-Sastre A, Martínez-Sobrido L: Multiple anti-interferon actions of the influenza A virus NS1 protein. J Virol 2007, 81(13):7011-7021.

14. Diaz MO, Ziemin S, Le Beau MM, Pitha P, Smith SD, Chilcote RR, Rowley JD: Homozygous deletion of the alpha- and beta 1-interferon genes in human leukemia and derived cell lines. Proc Natl Acad Sci USA 1988 85(14):5259-5263.

15. Mosca JD, Pitha PM: Transcriptional and posttranscriptional regulation of exogenous human beta interferon gene in simian cells defective in interferon synthesis. Mol Cell Biol 1986, 6(6):2279-2283.

16. Egorov A, Brandt S, Sereinig S, Romanova J, Ferko B, Katinger D, Grassauer A, Alexandrova G, Katinger H, Muster T: Transfectant Influenza A Viruses with Long Deletions in the NS1 Protein Grow Efficiently in Vero Cells. J Virol 1998, 72(8):6437-6441.

17. Wressnigg N, Shurygina AP, Wolff T, Redlberger-Fritz M, Popow-Kraupp T, Muster T, Egorov A, Kittel C: Influenza B mutant viruses with truncated NS1 proteins grow efficiently in Vero cells and are immunogenic in mice. J Gen Virol 2009, 90:366-374.

18. Efferson CL, Schickli J, Ko BK, Kawano K, Mouzi S, Palese P, García-Sastre A, loannides CG: Activation of tumor antigen-specific cytotoxic $T$ lymphocytes (CTLs) by human dendritic cells infected with an attenuated influenza A virus expressing a CTL epitope derived from the HER-2/neu proto-oncogene. J Virol 2003, 77(13):7411-7424.

19. Efferson CL, Tsuda N, Kawano K, Nistal-Villán E, Sellappan S, Yu D, Murray JL, García-Sastre A, loannides CG: Prostate Tumor Cells Infected with a Recombinant Influenza Virus Expressing a Truncated NS1 Protein Activate Cytolytic CD8+ Cells To Recognize Noninfected Tumor Cells. J Virol 2006, 80(1):383-394.

20. He Q, Martinez-Sobrido L, Eko FO, Palese P, Garcia-Sastre A, Lyn D, Okenu D, Bandea C, Ananaba GA, Black CM, et al: Live-attenuated influenza viruses as delivery vectors for Chlamydia vaccines. Immunology 2007, 122(1):28-37.

21. Genzel $Y$, Reichl U: Continuous cell lines as a production system for influenza vaccines. Expert Rev Vaccines 2009, 8(12):1681-1692.

22. Hu AY-C, Weng T-C, Tseng Y-F, Chen Y-S, Wu C-H, Hsiao S, Chou A-H, Chao H-J, Gu A, Wu S-C, et al: Microcarrier-based MDCK cell culture system for the production of influenza H5N1 vaccines. Vaccine 2008, 26(45):5736-5740.

23. Pau MG, Ophorst C, Koldijk MH, Schouten G, Mehtali M, Uytdehaag F: The human cell line PER.C6 provides a new manufacturing system for the production of influenza vaccines. Vaccine 2001, 19:2716-2721.

24. Ambrozaitis A, Groth N, Bugarini R, Sparacio V, Podda A, Lattanzi M: A novel mammalian cell-culture technique for consistent production of a well-tolerated and immunogenic trivalent subunit influenza vaccine. Vaccine 2009, 27(43):6022-6029.

25. Doroshenko A, Halperin SA: Trivalent MDCK cell culture-derived influenza vaccine Optaflu (Novartis Vaccines). Expert Rev Vaccines 2009, 8(6):679-688.

26. Genzel $Y$, Fischer $M$, Reichl U: Serum-free influenza virus production avoiding washing steps and medium exchange in large-scale microcarrier culture. Vaccine 2006, 24(16):3261-3272.

27. Genzel Y, Olmer RM, Schäfer B, Reichl U: Wave microcarrier cultivation of MDCK cells for influenza virus production in serum containing and serum-free media. Vaccine 2006, 24(35-36):6074-6087.

28. Ghendon YZ, Markushin SG, Akopova II, Koptiaeva IB, Nechaeva EA, Mazurkova LA, Radaeva IF, Kolokoltseva TD: Development of cell culture (MDCK) live cold-adapted (CA) attenuated influenza vaccine. Vaccine 2005, 23(38):4678-4684

29. Liu J, Mani S, Schwartz R, Richman L, Tabor DE: Cloning and assessment of tumorigenicity and oncogenicity of a Madin-Darby canine kidney (MDCK) cell line for influenza vaccine production. Vaccine 2010, 28(5):1285-1293.

30. Liu J, Shi X, Schwartz R, Kemble G: Use of MDCK cells for production of live attenuated influenza vaccine. Vaccine 2009, 27(46):6460-6463.

31. Hu W-S, Giard DJ, Wang DIC: Serial Propagation of Mammalian Cells on Microcarriers. Biotechnol Bioeng 1985, 27(10):1466-1476.

32. Kistner O, Barrett PN, Mundt W, Reiter M, Schober-Bendixen S, Dorner F: Development of a mammalian cell (Vero) derived candidate influenza virus vaccine. Vaccine 1998, 16(9-10):960-968.

33. Ng Y-C, Berry JM, Butler M: Optimization of physical parameters for cell attachment and growth on macroporous microcarriers. Biotechnol Bioeng 1996, 50(6):627-635.

34. Yokomizo AY, Antoniazzi MM, Galdino PL, A N Jr, Jorge SAC, Pereira CA: Rabies virus production in high vero cell density cultures on macroporous microcarriers. Biotechnol Bioeng 2004, 85(5):506-515.

35. Genzel Y, Dietzsch C, Rapp E, Schwarzer J, Reichl U: MDCK and Vero cells for influenza virus vaccine production: a one-to-one comparison up to lab-scale bioreactor cultivation. Appl Microbiol Biotechnol 2010, 88(2):461-475.

36. Cinatl JJ, Cinatl J, Rabenau H, Rapp J, Kornhuber B, Doerr H: Protein-free culture of Vero cells: A substrate for replication of pathogenic viruses. Cell Biol Int 1993, 17(9):885-895.

37. Merten O-W, Kierulff JV, Castignolles N, Perrin P: Evaluation of the new serum free medium (MDSS2) for the production of different biologicals: use of various cell lines. Cytotechnology 1994, 14(1):47-59.

38. Yuk IH, Lin GB, Ju H, Sifi I, Lam Y, Cortez A, Liebertz D, Berry JM, Schwartz RM: A serum-free Vero production platform for a chimeric virus vaccine candidate. Cytotechnology 2006, 51:183-192.

39. Rourou S, van der Ark A, van der Velden T, Kallel H: A microcarrier cell culture process for propagating rabies virus in Vero cells grown in a stirred bioreactor under fully animal component free conditions. Vaccine 2007, 25(19):3879-3889.

40. Tiwari M, Parida M, Santhosh SR, Khan M, Dash PK, Rao PVL: Assessment of immunogenic potential of Vero adapted formalin inactivated vaccine derived from novel ECSA genotype of Chikungunya virus. Vaccine 2009, 27(18):2513-2522.

41. Souza MCO, Freire MS, Schulze EA, Gaspar LP, Castilho LR: Production of yellow fever virus in microcarrier-based vero cell cultures. Vaccine 2009, 27(46):6420-6423.

42. Silva AC, Delgado I, Sousa MFQ, Carrondo MJT, Alves PM: Scalable culture systems using different cell lines for the production of Peste des Petits ruminants vaccine. Vaccine 2008, 26:3305-3311.

43. Liu C-C, Lian W-C, Butler M, Wu S-C: High immunogenic enterovirus 71 strain and its production using serum-free microcarrier Vero cell culture. Vaccine 2007, 25(1):19-24.

44. Butler M, Burgener A, Patrick M, Berry M, Moffatt D, Huzel N, Barnabé N, Coombs K: Application of a Serum-Free Medium for the Growth of Vero Cells and the Production of Reovirus. Biotechnol Prog 2000, 16(5):854-858. 
45. Rourou S, van der Ark A, Majoul S, Trabelsi K, van der Velden T, Kallel H: A novel animal-component-free medium for rabies virus production in Vero cells grown on Cytodex 1 microcarriers in a stirred bioreactor. Appl Microbiol Biotechnol 2009, 85(1):53-63.

46. Petiot E, Fournier F, Gény C, Pinton H, Marc A: Rapid Screening of SerumFree Media for the Growth of Adherent Vero Cells by Using a SmallScale and Non-invasive Tool. Appl Biochem Biotechnol 2010, 160(6):1600-1615.

47. Frazzati-Gallina NM, Paoli RL, Mourão-Fuches RM, Jorge SAC, Pereira CA: Higher production of rabies virus in serum-free medium cell cultures on microcarriers. J Biotechnol 2001, 92:67-72.

48. Quesney S, Marvel J, Gerdil C, Meignier B: Characterization of Vero cell growth and death in bioreactor with serum-containing and serum-free media. Cytotechnology 2001, 35:115-125.

49. Souza MCdO, Freire MdS, Castilho LdR: Influence of Culture Conditions on Vero Cell Propagation on Non-Porous Microcarriers. Braz Arch Biol Technol 2005, 48:71-77.

50. Quesney Sb, Marc A, Gerdil C, Gimenez C, Marvel J, Richard Y, Meignier B: Kinetics and metabolic specificities of Vero cells in bioreactor cultures with serum-free medium. Cytotechnology 2003, 42:1-11.

51. Wood HA, Johnston LB, Burand JP: Inhibition of Autographa californica Nuclear Polyhedrosis Virus Replication in High-Density Trichoplusia ni Cell Culture. Virology 1982, 119:245-254.

52. Kamen A, Henry O: Development and optimization of an adenovirus production process. J Gene Med 2004, 6:S184-S192.

53. Yuk IHY, Olsen MM, Geyer S, Forestell SP: Perfusion cultures of human tumor cells: a scalable production platform for oncolytic adenoviral vectors. Biotechnol Bioeng 2004, 86(6):637-642.

54. Bock A, Schulze-Horsel J, Rapp E, Genzel Y, Reichl U: High-Density Microcarrier Cell Cultures for Influenza Virus Production. Biotechnol Prog 2011, 27(1):241-250.

55. Ghani K, Garnier A, Coelho H, Transfiguracion J, Trudel P, Kamen A: Retroviral vector production using suspension-adapted 293GPG cells in a $3 \mathrm{~L}$ acoustic filter-based perfusion bioreactor. Biotechnol Bioeng 2006, 95(4):653-660.

56. Merten O-W: State-of-the-art of the production of retroviral vectors. J Gene Med 2004, 6:S105-S124.

57. Beer C, Meyer A, Müller K, Wirth M: The temperature stability of mouse retroviruses depends on the cholesterol levels of viral lipid shell and cellular plasma membrane. Virology 2003, 308(1):137-146.

58. Le Rub A, Jacob D, Transfiguracion J, Ansorge S, Henry O, Kamen AA: Scalable production of influenza virus in HEK-293 cells for efficient vaccine manufacturing. Vaccine 2010, 28(21):3661-3671.

59. Barber GN: Host defense, viruses and apoptosis. Cell Death Differ 2001, 8(2):113-126.

60. Bergmann M, Garcia-Sastre A, Carnero E, Pehamberger $H$, Wolff K, Palese $P$, Muster T: Influenza Virus NS1 Protein Counteracts PKR-Mediated Inhibition of Replication. J Virol 2000, 74(13):6203-6206.

61. Hayman A, Comely S, Lackenby A, Hartgroves LCS, Goodbourn S, McCauley JW, Barclay WS: NS1 proteins of avian influenza A viruses can act as antagonists of the human alpha/beta interferon response. J Virol 2007, 81(5):2318-2327.

62. Ehrhardt C, Ludwig S: A new player in a deadly game: influenza viruses and the PI3K/Akt signaling pathway. Cell Microbiol 2009, 11(6):863-871.

63. Zhirnov OP, Konakova TE, Wolff T, Klenk HD: NS1 Protein of Influenza A Virus Down-Regulates Apoptosis. J Virol 2002, 76(4):1617-1625.

64. Ehrhardt C, Wolff T, Ludwig S: Activation of phosphatidylinositol 3-kinase signaling by the nonstructural NS1 protein is not conserved among type A and B influenza viruses. J Virol 2007, 81(21):12097-12100.

65. Seitz C, Frensing T, Höper D, Kochs G, Reichl U: High yields of Influenza A virus in MDCK cells are promoted by an insufficient IFN-induced antiviral state. J Gen Virol 2010, 91(7):1754-1763.

66. Genzel Y, Behrendt I, Konig S, Sann H, Reichl U: Metabolism of MDCK cells during cell growth and influenza virus production in large-scale microcarrier culture. Vaccine 2004, 22:2202-2208.

67. Matlin KS: Ammonium Chloride Slows Transport of the Influenza Virus Hemagglutinin but Does Not Cause Mis-sorting in a Polarized Epthelial Cell Line. J Biol Chem 1986, 261(32):15172-15178.

68. Morris SJ, Price GE, Barnett JM, Hiscox SA, Smith H, Sweet C: Role of neuraminidase in influenza virus-induced apoptosis. J Gen Virol 1999, 80:137-146.
69. Whittaker G, Bui M, Helenius A: The role of nuclear import and export in influenza virus infection. Trends Cell Biol 1996, 6:67-71.

70. Cox N: WHO manual on animal influenza diagnosis and surveillance. In WHO Animal Influenza Manual. Edited by: Webster RG, Krauss S. Geneva: World Health Organization; 2002:1-97.

71. Reed $L$, Muench $H$ : A simple method of estimating fifty per cent endpoints. The American Journal of Hygiene 1938, 27(3):493-497.

72. Karrona RA, Talaat K, Luke C, Callahan K, Thumar B, DiLorenzo S, McAuliffe J, Schappell E, Suguitan A, Mills K, et al: Evaluation of two live attenuated cold-adapted H5N1 influenza virus vaccines in healthy adults. Vaccine 2009, 27:4953-4960.

73. Talaat KR, Karrona RA, Callahan KA, Luke CJ, DiLorenzo SC, Chen GL, Lamirande EW, Jin $\mathrm{H}$, Coelingh $\mathrm{KL}$, Murphy BR, et al: A live attenuated H7N3 influenza virus vaccine is well tolerated and immunogenic in a Phase I trial in healthy adults. Vaccine 2009, 27:3744-3753.

doi:10.1186/1472-6750-11-81

Cite this article as: Chen et al:: Serum-free microcarrier based

production of replication deficient Influenza vaccine candidate virus lacking NS1 using Vero cells. BMC Biotechnology 2011 11:81.

\section{Submit your next manuscript to BioMed Central and take full advantage of:}

- Convenient online submission

- Thorough peer review

- No space constraints or color figure charges

- Immediate publication on acceptance

- Inclusion in PubMed, CAS, Scopus and Google Scholar

- Research which is freely available for redistribution

Submit your manuscript at www.biomedcentral.com/submit
Biomed Central 